\title{
Detection of genes influencing economic traits in three French dairy cattle breeds
}

\author{
Didier Boichard ${ }^{\mathrm{a} *}$, Cécile Grohs ${ }^{\mathrm{b}}$, \\ Florence Bourgeois ${ }^{\mathrm{c}}$, Frédérique CerqueIrA ${ }^{\mathrm{c}}$, \\ Rémi Faugeras ${ }^{\mathrm{c}}$, André Neau ${ }^{\mathrm{d}}$, Rachel Rupp ${ }^{\mathrm{a}}$, Yves Amigues ${ }^{\mathrm{c}}$, \\ Marie Yvonne Boscher ${ }^{\mathrm{c}}$, Hubert Levéziel ${ }^{\mathrm{b}}$ \\ a Station de génétique quantitative et appliquée, \\ Institut national de la recherche agronomique, 78352 Jouy-en-Josas Cedex, France \\ ${ }^{\mathrm{b}}$ Laboratoire de génétique biochimique et de cytogénétique, \\ Institut national de la recherche agronomique, 78352 Jouy-en-Josas Cedex, France \\ ${ }^{c}$ GIE Labogena, 78352 Jouy-en-Josas Cedex, France \\ d Département de génétique animale, Institut national de la recherche agronomique, \\ 78352 Jouy-en-Josas Cedex, France
}

(Received 25 February 2002; accepted 20 September 2002)

\begin{abstract}
A project of QTL detection was carried out in the French Holstein, Normande, and Montbéliarde dairy cattle breeds. This granddaughter design included 1548 artificial insemination bulls distributed in 14 sire families and evaluated after a progeny-test for 24 traits (production, milk composition, persistency, type, fertility, mastitis resistance, and milking ease). These bulls were also genotyped for 169 genetic markers, mostly microsatellites. The QTL were analysed by within-sire linear regression of daughter yield deviations or deregressed proofs on the probability that the son receives one or the other paternal QTL allele, given the marker information. QTL were detected for all traits, including those with a low heritability. One hundred and twenty QTL with a chromosome-wise significance lower than 3\% were tabulated. This threshold corresponded to a $15 \%$ false discovery rate. Amongst them, 32 were genomewise significant. Estimates of their contribution to genetic variance ranged from 6 to $40 \%$. Most substitution effects ranged from 0.6 to 1.0 genetic standard deviation. For a given QTL, only 1 to 5 families out of 14 were informative. The confidence intervals of the QTL locations were large and always greater than $20 \mathrm{cM}$. This experiment confirmed several already published QTL but most of them were original, particularly for non-production traits.
\end{abstract}

dairy cattle / QTL detection / genetic marker / granddaughter design

\footnotetext{
* Correspondence and reprints

E-mail: boichard@dga.jouy.inra.fr
} 


\section{INTRODUCTION}

Livestock species have been selected for a long time with the aim of improving traits of economic interest. These traits usually have a complex determinism, affected by an unknown number of genes and by environmental factors. The selection strategy has been based on the prediction of the overall genetic merit of the individuals from the phenotypic and pedigree information with appropriate statistical tools. This selection has been shown to be very efficient, although it is based on the wrong biological model and most genes involved are still unknown.

In the last decade, however, advances in molecular genetics have made it possible to dissect the genetic variability of complex traits into quantitative trait loci. A QTL is defined as a chromosomal segment with a Mendelian transmission pattern and with an effect on the trait of interest. QTL detection is the first step towards the identification of the genes involved and of the causal mutations. Moreover, even if the genes involved are still unknown, individual QTL information could enhance selection efficiency and is known to be particularly beneficial when the trait is difficult or expensive to measure, when each individual performance brings little information, or, more generally, when the polygenic approach has a limited efficiency or a high cost. It is believed that marker-assisted selection (MAS) could be particularly profitable in dairy cattle. Indeed, this species concentrates many conditions unfavourable to phenotypic selection and, therefore, favourable to MAS: most traits of interest are sex-limited; the generation interval is long; artificial insemination bulls should be progeny tested before extensive use, which is a long and costly step; the breeding schemes are more and more designed with bull dams selected before their first lactation on pedigree information only, in order to reduce the generation interval; last but not least, functional traits, such as disease resistance or fertility, have a low heritability but are more and more important in the breeding goal. Since AI is predominant, the number of key animals in the breeding scheme is limited and makes MAS relatively easy to implement. Although MAS could be oriented towards increasing the genetic trend on the current objective or modifying the breeding objective by efficiently including low heritability traits, the breeders most likely will use it to decrease the cost of the breeding programme by reducing the number of bulls sampled.

Before implementing MAS, accurate information is required on the QTL responsible for the major part of the genetic variability of the important traits. In dairy cattle, the population structure can be used to implement the so-called granddaughter design [11,32]. After the pioneering work of Georges et al. [12], several large projects have been carried out all over the world. In this paper, we present the results of a large QTL detection experiment carried out in the French dairy cattle AI populations. 


\section{MATERIALS AND METHODS}

\subsection{Material}

The QTL experiment was a typical granddaughter design [32] including three generations: bull sires, artificial insemination (AI) sons, and granddaughters. Only males of generations 1 and 2 were genotyped for genetic markers, whereas the granddaughters were recorded for phenotypic traits and were used to predict the genetic merit of their sire. The advantages of such a design are: (1) its cost limited to the genotyping work because the population structure and the phenotypic data already exist for selection purposes; (2) its high detection power, due to the definition of the trait, similar to a mean and, therefore, with a small residual variance; and (3) its relative ease of implementation because DNA could be extracted from semen which is readily available.

In the present study, the design included 1554 AI bulls distributed in 14 half-sib families (9 in Holstein, 3 in Normande, and 2 in Montbéliarde breeds). Family size averaged 111 sons per sire and ranged from 59 to 232. Large families were chosen to ensure a high detection power. The sons were born from 1988 to 1992 . The DNA was obtained from the semen bank maintained at Inra with the help of the French AI coops. AI bulls were progeny tested with 85 daughters on average. Phenotypic traits were those routinely collected and evaluated for selection purposes. They included production (milk, fat, and protein yields), milk content (fat and protein percentage), protein yield persistency (100-200 day yield over 100-day yield ratio), mastitis resistance (milk somatic cell score), milking speed (subjective appraisal given by the farmers), female post partum fertility (success/failure of each insemination of the daughters), udder morphology (udder cleft, udder depth, udder balance, implantation, teat placement front, teat distance side view, teat length, rear udder attachment), rump (length, width, angle), stature (height at sacrum, chest depth), and feet and leg characteristics (rear leg set, heel depth). More details about the definition of the traits and characteristics of the corresponding genetic evaluations can be found in $[17,18]$.

\subsection{Methods}

The genetic markers were mostly microsatellites selected on the basis of their informativity (at least 8 sires out of 14 should be heterozygous), their location on the genome, and their technical quality. Three hundred microsatellites were tested and 157 were selected, assembled in 17 sets, and genotyped with a $377 \mathrm{ABI}^{\circledR}$ sequencer. For PCR amplification, the number of markers amplified in the same PCR multiplex ranged from 1 to 8 and reached 5 on average. All technical information relative to the markers (number of alleles and frequencies, informativity, genetic map) and to the 
design of sets (multiplex PCR conditions) are available at the following web site: http://locus.jouy.inra.fr/lgbc/tab_qtl.html. All 1568 males (14 sires and 1554 sons) were typed for the 157 markers, even when the sire was homozygous for a marker. The genotypes were obtained through two independent softwares, Genotyper ${ }^{\circledR}$ (P.E. Biosystems, ABI Prism ${ }^{\mathrm{TM}}$ ) and Gemma [16]. In case of missing or doubtful results after a first run, the samples were reloaded and completely analysed a second time. A total of 242223 genotypes were obtained, i.e. 240025 from the progeny and 2198 from the sires. Eleven blood group markers were also included. Since they were used for parentage testing, this information was available for most AI bulls from the Labogena data base. Because their determinism is dominant, the interpreted genotypes were used, instead of the raw phenotypes, in order to analyse the codominant markers only. Similarly, the Blad gene was informative in three families and was also included. Additional blood groups (15715) and Blad genotypes were used, yielding to a total of 257938 genotypes for the 169 markers. The markers covered the 29 autosomes and their complete list is presented in Table I. Because all genotyped progeny were males, they all received the chromosome $\mathrm{Y}$ from their sire, and we neglected the pseudo-autosomal region. The number of markers per chromosome ranged from 3 to 10 .

QTL detection was carried out in two steps [10]: (a) For each chromosome, the probability of each possible phase of the sires was estimated from progeny marker information, the most likely phase was retained, and the probability that each progeny received one or the other chromosomal segment was estimated at every position, given this phase; and (b) QTL detection sensu stricto was carried out by within-sire linear regression [20]. All positions were tested with a $1 \mathrm{cM}$ step. The model was the following:

$$
y_{i j}=s_{i}+\left(2 p_{i j}-1\right) a_{i}+e_{i j} .
$$

The dependent variable $y_{i j}$ was twice the so-called daughter yield deviation (DYD, [29]), i.e. the average performance of the $n_{i j}$ daughters of son $j$ of sire $i$, adjusted for the environmental effects and genetic merit of the dam. In practice, DYD were obtained from the French genetic evaluation system. For type and fertility, the DYD was estimated by proof de-regression. For each location $x$ on the genome, $s_{i}$ was the effect of sire $i, a_{i}$ was half the substitution effect of the putative QTL carried by the sire, and $p_{i j}$ was the probability of inheriting one arbitrarily defined QTL allele from sire $i$ for son $j$, given the marker information. Finally, $e_{i j}$ was the residual, assumed to be normally distributed with a zero expectation and a heterogeneous variance approximately equal to $\sigma_{e_{i}}^{2} / C D_{i j}$ [33], where $C D_{i j}$ is the reliability of the proof based on progeny information only. The residual variance was defined within-sire family to improve detection robustness [13] and also to simultaneously analyse the traits expressed in different breeds and, possibly, on different scales. In this approach, 
all parameters (sire and QTL effects, variances) were defined within-family, and the overall likelihood ratio test was simply the sum of the family contributions.

Alternatively, the QTL effect was also considered as a random effect assumed to be normally distributed. We used the method proposed by Goffinet et al. [13]. The parameters to estimate were the fixed sire effect, the QTL variance $\sigma_{q}^{2}$ and the overall residual variance $\sigma_{e}^{2}$. Because the sire effect was assumed to be fixed, the sum of the QTL and residual variances $\left(\sigma_{e}^{2}+\sigma_{q}^{2}\right)$ represented 0.75 total genetic variance. On the contrary, $\sigma_{q}^{2}$ represented the variance of paternal QTL Mendelian sampling, i.e. only a quarter of the variance due to the QTL in the population. Therefore the part of the genetic variance due to the QTL in the whole population was estimated by $4 \sigma_{q}^{2} /\left[\left(\sigma_{e}^{2}+\sigma_{q}^{2}\right) / 0.75\right]$, i.e. by $3 \sigma_{q}^{2} /\left(\sigma_{e}^{2}+\sigma_{q}^{2}\right)$.

Because of the multiplicity of the correlated tests along the chromosome, the theoretical distribution of the maximum likelihood test under $\mathrm{H} 0$ was unknown and rejection thresholds were estimated by within-family permutations [7], separately for each trait and each chromosome. Ten thousand permutations were computed for each trait by chromosome combination and, for each permutation, the highest likelihood ratio test value over the chromosome was retained. This empirical distribution of tests under $\mathrm{H} 0$ was used to define the critical thresholds. When the first estimate of the probability of no QTL for a given trait by chromosome combination was below $0.5 \%$, the critical thresholds were re-estimated from 100000 permutations. Because of the large number of traits analysed (24 traits, corresponding to about 15 independent traits), accounting for the number of traits in the definition of critical thresholds is believed to be meaningless and would result in the following paradox that less QTL are found when more traits are analysed. We consider that it is preferable to control the false discovery rate of QTL [33]. The results are presented according to three levels of significance: (a) a genome-wise significance of $10 \%$, corresponding to a nominal significance of $0.34 \%$ and 29 chromosomes analysed (this corresponded to about 0.1 false positive expected per trait, and about 2 false positive expected for all traits); (b) a chromosome-wise significance of $1 \%$, corresponding to about 7 false positive results expected out of the $24 \times 29=696$ analyses performed; and (c) a chromosome-wise significance of $3 \%$, chosen according to the distribution of $P$-values and the trend in a false discovery rate.

The number of informative families, i.e. with a sire heterozygous for a detected QTL, was estimated as follows. Assuming that the QTL exists and given its location, there is only one remaining parameter per family, the withinsire QTL effect. The sire was considered to be heterozygous at the $P$ level if the family contribution to the overall likelihood ratio test exceeded the value of a $\chi^{2}$ distribution with one degree of freedom and probability $P$.

The confidence intervals of the QTL location were estimated by lod drop-off and by bootstrap [31]. In the first approach, the 5\% confidence interval was 
defined as the interval bounded by the two locations whose likelihood was equal to the maximum likelihood minus $3.84\left(=\chi_{(1,0.05)}^{2}\right)$. In the second approach, the empirical sampling distribution of the location was estimated by repeatedly analysing a data set of the same size, randomly sampled within-family in the original data set. Because the distribution of the location of the maximum likelihood under $\mathrm{H} 0$ was not uniformly distributed over the chromosome but presented accumulations at the marker location, bootstrap location results were weighed by the inverse of the location frequencies observed under H0 [4], leading to smaller confidence intervals. These location frequencies under $\mathrm{H} 0$ were obtained with the permutation results.

A 2-QTL analysis was also carried out by regression, in order to test for the presence of two linked QTL on the same chromosome. A two-dimensional search was performed where all combinations of the positions of the two QTL were evaluated, and the combination with the highest likelihood was retained. These two locations were also analysed with the one-QTL model. The oneQTL hypothesis was rejected if the two-QTL model was significantly better than both one-QTL models.

\section{RESULTS}

\subsection{Characteristics of the markers and the genetic map}

Because of their selection, microsatellites were highly informative, as shown in Table I. Over the 169 loci, the sire heterozygosity reached $68 \%$ on average and ranged from 63.9 to $73.4 \%$ according to the sires. It was higher for the microsatellites (70\%) than for the 12 other loci $(48 \%)$. Six progeny were found to be incompatible with their sires. After the first three marker sets, they were found to be incompatible with at least 7 markers out of 24 . These progeny were not genotyped for the other markers and were simply disregarded in subsequent analyses, without attempting to determine whether this was due to wrong pedigree information, a mistake in semen processing, or a manipulation error in DNA preparation. After excluding these data, 239845 microsatellite genotypes of 1548 progeny were obtained, corresponding to a readability of $98.5 \%$. After checking, 318 additional genotypes were found to be incompatible, out of them 154 were concentrated on six markers: CSSM026 (91), IDVGA71 (27), INRA081 (14), CSSMO18 (12), and BM741 (10). Out of the 1548 progeny, $1284,233,21,4,3$, and 3 showed $0,1,2,3,4$, and 6-8 incompatibilities. These individual genotypes were deleted from further analysis. Out of the 239527 progeny microsatellite compatible genotypes, 157876 (66\%) were different from those of the sire and were fully informative.

A specific genetic map was built. The chromosome assignation was in agreement with the published maps $[3,19]$, as well as the marker order, but 
Table I. Characteristics of the 157 microsatellites.

\begin{tabular}{lcc}
\hline & Mean & Standard deviation \\
\hline Nr genotypes / marker & 1526 & 20 \\
Nr heterozygous sires (out of 14) & 9.9 & 2.1 \\
Nr informative meioses & 1007 & 188 \\
Nr Alleles in the dam population & 9.0 & 3.2 \\
PIC $^{(1)}$ in the dam population & 0.635 & 0.134 \\
\hline
\end{tabular}

(1) $\mathrm{PIC}=$ polymorphism information content.

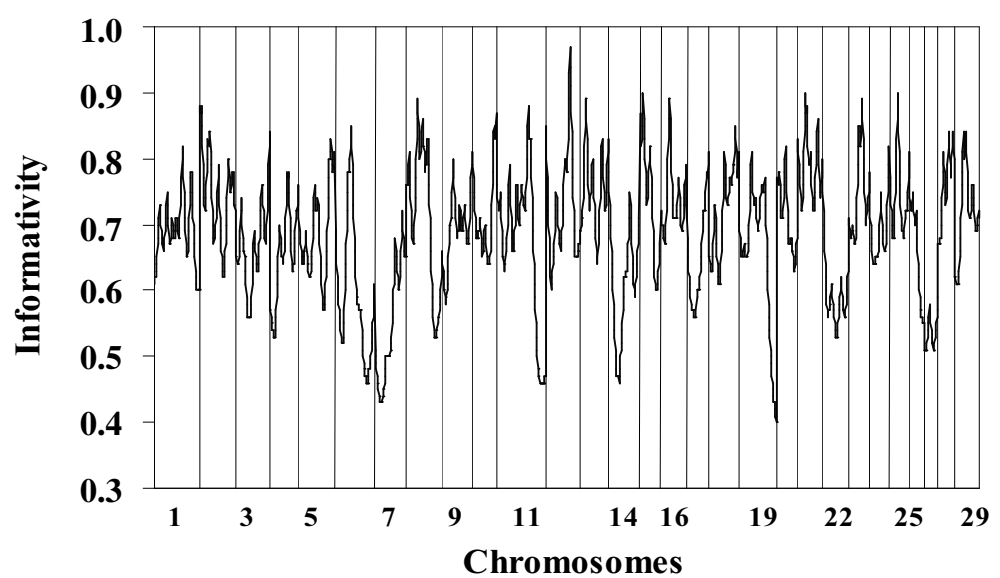

Figure 1. Information content of the markers used, measured by the mean $\left|1-2 p_{i j}\right|$, over the whole genome. The limits between chromosomes are reported by vertical lines.

genetic distances were often quite different (Tab. II). Two genes, the locations of which were unknown when the project started, were mapped with this design. The $C D 18$ gene, responsible for the Blad syndrome, was mapped on chromosome 1, between UWCA46 (12 cM Haldane) and BMS2263 $(21 \mathrm{cM})$. The $E A F$ blood group was mapped on chromosome 17, between BMS499 $(25 \mathrm{cM})$ and $B M S 2780(15 \mathrm{cM})$, in agreement with [28]. More generally, the location of the eleven blood groups was updated (Tab. II). The total map spanned $3353 \mathrm{cM}$ Haldane or $2731 \mathrm{cM}$ Kosambi. Among the 128 segments between microsatellite markers, $10,29,42,34,8,4$, and 1 were in the $[0,10]] 10,20]] 20,30]] 30,40]] 40,50]] 50,60$,$] , and ]60, 70] intervals$ (cM Haldane), respectively. The average information content over the whole genome, measured by the mean of $\left|2 p_{i j}-1\right|$ over all locations and all progeny, is presented in Table II and reached 0.685. Figure 1 shows that it was lower than $50 \%$ in the five chromosomal regions. 


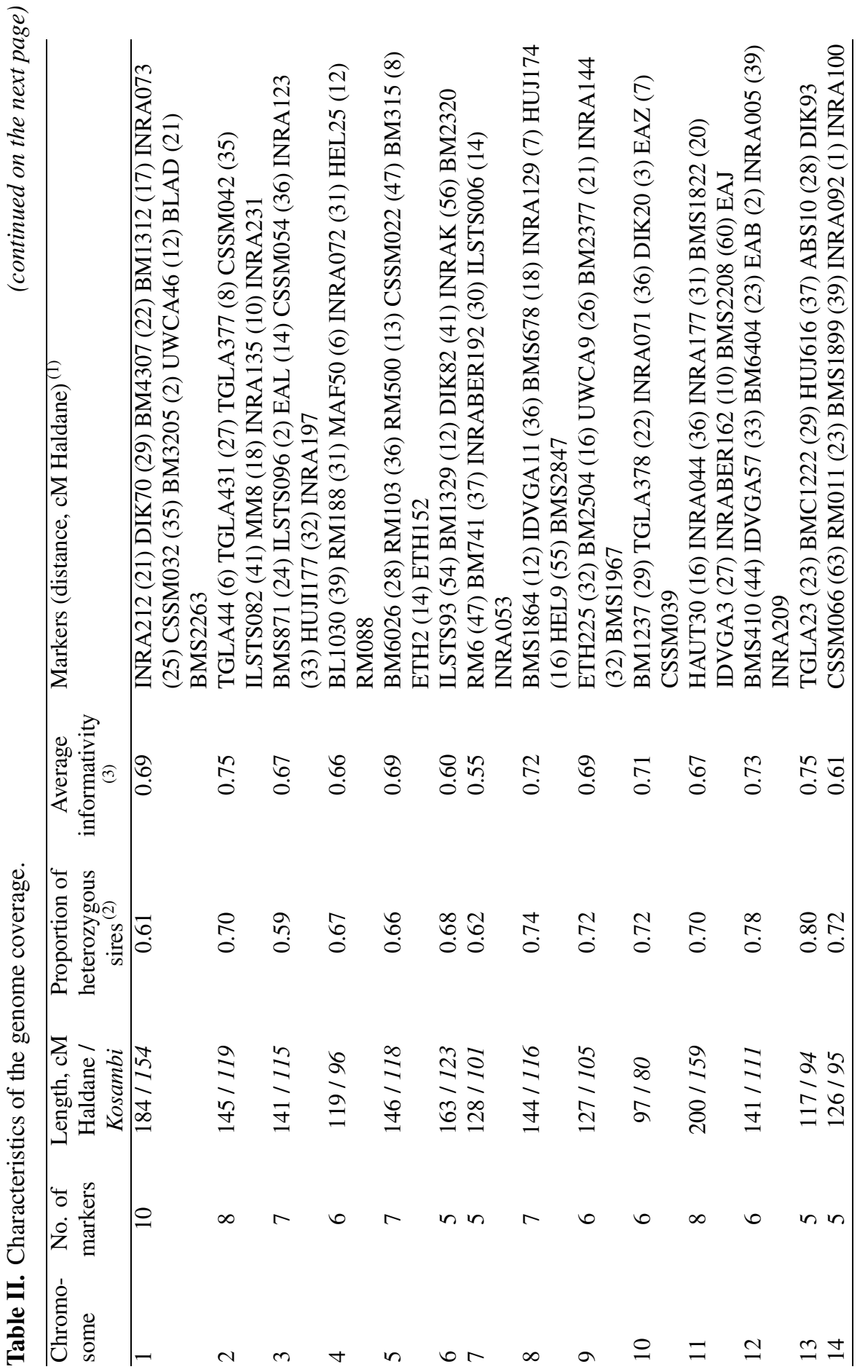




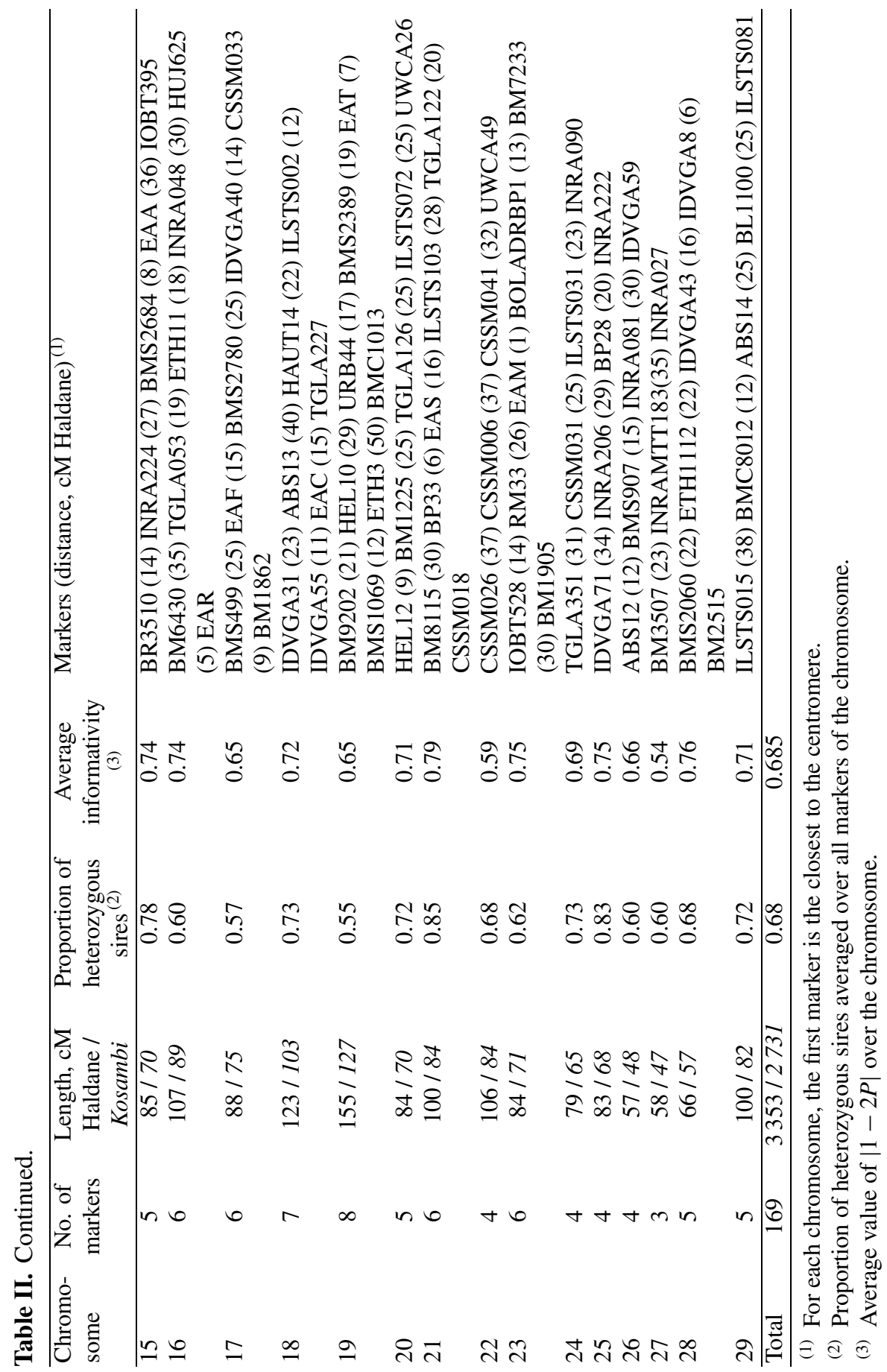


Table III. Distribution of the observed $P$-values over all analyses $(n=696)$.

\begin{tabular}{cc}
\hline$P$ value $(\%)$ & Frequency $(\%)$ \\
\hline $0-1$ & 8.7 \\
$1-2$ & 5.1 \\
$2-3$ & 3.9 \\
$3-4$ & 2.7 \\
$4-5$ & 3.1 \\
$5-10$ & 8.7 \\
$10-50$ & 41.6 \\
$50-100$ & 26.2 \\
\hline
\end{tabular}

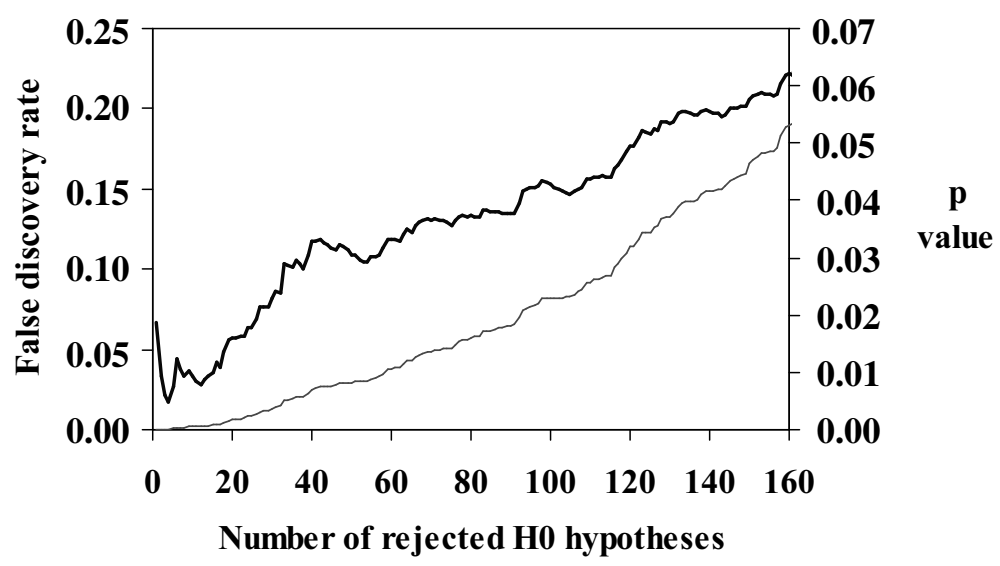

Figure 2. Evolution of the false discovery rate (bold) and the chromosome-wise type-1 error (thin) with the number of rejected null hypotheses.

\subsection{QTL results}

The distribution of the $P$-values obtained for 696 chromosome $\times$ trait combinations analysed is presented in Table III. A high concentration of $P$-values (18\%) was observed between 0 and $3 \%$ and a clear overrepresentation could still be noticed up to $10 \%$. Figure 2 presents the false discovery rate as a function of the number of rejected $\mathrm{H} 0$ hypotheses. The false discovery rate was extremely low $(<5 \%)$ for the 20 most significant results. It gradually increased up to $12 \%$ for the next 20 tests, and more slowly increased for the next 80 tests. For a $3 \% P$-value, the false discovery rate was only around $15 \%$, showing that more than 100 significant tests out of 120 likely corresponded to true QTL. 
Thirty-two results were genome-wise (or nearly genome-wise) significant (Tab. IV), 22 results had a chromosome-wise significance level ranging from 0.34 to $1 \%$ (Tab. V), and 66 additional results had a significance level ranging from 1 to $3 \%$ (Tab. VI). In all cases, the number of informative sires (i.e. heterozygous for the QTL) was limited and ranged from 1 to 5 out of 14 .

QTL were found for all traits. Figure 3 presents some of the most interesting results in a standardised way, where the $y$-axis represents $\log _{10}(1 / P)$. QTL for production were detected on chromosomes 7, 14, 19, and 26. Chromosome 11 was found to affect the lactation persistency whereas the effect on production was more limited. Chromosomes 3, 6, 7, 14, 18, and 20 affected fat or protein content, or both traits. A strong QTL of somatic cell score was found on chromosome 15, as well as three other putative QTL on chromosomes 9, 10, and 21. Female fertility was influenced by QTL on chromosome 1, 7, and possibly 21. A major QTL for skeletal development was detected on chromosome 5, and two others on chromosomes 6 and 13. Chromosome 28 was found to strongly affect the udder cleft, implantation, and teat placement front, which are correlated traits. The other udder traits were affected by other regions: chromosomes $9,18,19$, and 20 for udder balance, 2, 12, and 13 for teat distance side view, chromosome 27 for teat length. Three putative QTL were also found for milking speed on chromosome 6,8 , and 13. Rump angle was characterised by 3 QTL on chromosome 1, 13, and 19, whereas heel depth was affected by one QTL on chromosome 15.

Most substitution effect estimates ranged from 0.6 to 1 genetic standard deviation. Estimates of QTL contributions to the genetic variance are shown in Table VII. They ranged from 6 to $40 \%$ but most estimates were between 7 and $18 \%$.

The confidence intervals of QTL location estimated by bootstrap were much larger than those estimated by the lod drop-off method (Tabs. IV and V). In the best situations, they ranged from 14 to $30 \mathrm{cM}$ but they frequently exceeded $50 \mathrm{cM}$ and sometimes included the complete chromosome. An illustration of the bootstrap distribution is given in Figure 4 for SCS on chromosome 15.

The two-QTL analysis provided little additional information (Tab. VIII). Two linked QTL were suggested for fertility on chromosome 1, rump width on chromosome 5, protein yield on chromosome 18, fat yield on chromosome 19, and heel depth on chromosome 24 . On chromosome 15, the two-QTL model was better than the one-QTL models but the locations were quite close to each other. In all cases, the evidence was not strong for the 2-QTL hypothesis.

\section{DISCUSSION AND CONCLUSION}

Many results are reported in this paper. This high number of significant results is explained on the one hand by the large number of traits analysed 
Table IV. Genome-wise significant QTL (chromosomewise significance with $P<0.34 \%)$.

\begin{tabular}{|c|c|c|c|c|c|c|c|}
\hline Trait & $\begin{array}{l}\text { Chromo- } \\
\text { some }\end{array}$ & $P(\%)$ & $\begin{array}{l}\text { Location } \\
\text { of } \\
\text { naximum }^{(1)}\end{array}$ & Closest marker & $\begin{array}{l}\text { Location confidence } \\
\text { interval }(\mathrm{cM})^{(2)}\end{array}$ & $\begin{array}{l}\text { Number } \\
\text { of hetero- } \\
\text { zygous } \\
\text { sires }\end{array}$ & $\begin{array}{l}\text { Average } \\
\text { substitu- } \\
\text { tion effect } \\
\quad\left(\sigma_{g}\right)\end{array}$ \\
\hline Milk & 14 & 0.02 & 0 & CSSM066 & $0-25 / 0-43$ & 4 & 0.82 \\
\hline \multirow[t]{3}{*}{ Fat } & 14 & 0.11 & 0 & CSSM066 & $0-42 / 0-108$ & 2 & 1.04 \\
\hline & 19 & 0.13 & 134 & BMC1013 & $88-154 / 12-132$ & 4 & 0.98 \\
\hline & 26 & $<0.001$ & 57 & IDVGA59 & $20-51 / 12-57$ & 4 & 1.02 \\
\hline \multirow[t]{2}{*}{ Protein } & 7 & 0.29 & 84 & INRABERN192 & $71-90 / 30-90$ & 2 & 0.70 \\
\hline & 26 & 0.04 & 57 & IDVGA59 & $18-51 / 11-57$ & 3 & 0.81 \\
\hline Fat percent & 14 & $<0.001$ & 0 & CSSM066 & $0-9 / 0-19$ & 4 & 1.25 \\
\hline \multirow[t]{3}{*}{ Protein percent } & 6 & 0.04 & 98 & INRAK & $84-129 / 82-129$ & 3 & 0.77 \\
\hline & 14 & $<0.001$ & 0 & CSSM066 & $0-70 / 7-82$ & 4 & 1.25 \\
\hline & 20 & 0.35 & 38 & TGLA126 & $21-50 / 11-53$ & 3 & 0.68 \\
\hline Persistency & 11 & 0.19 & 124 & INRABERI62 & $115-138 / 88-140$ & 2 & 0.80 \\
\hline SCS & 15 & 0.05 & 40 & $B M S 2684$ & $35-45 / 22-48$ & 2 & 0.64 \\
\hline Udder cleft & 28 & 0.27 & 4 & $B M S 2060$ & $0-18 / 0-61$ & 3 & 0.68 \\
\hline \multirow[t]{2}{*}{ Udder balance } & 18 & 0.05 & 98 & IDVGA55 & $90-115 / 70-118$ & 4 & 0.78 \\
\hline & 19 & 0.33 & 30 & HEL10 & $19-62$ / 20-95 & 2 & 0.82 \\
\hline Teat distance & 12 & 0.03 & 88 & BM6404 & $78-100 / 57-105$ & 4 & 0.57 \\
\hline side view & 13 & 0.05 & 8 & $T G L A 23$ & $0-44 / 0-58$ & 2 & 0.72 \\
\hline Implantation & 28 & 0.04 & 4 & $B M S 2060$ & $0-17 / 0-47$ & 2 & 1.47 \\
\hline Teat length & 27 & 0.02 & 40 & INRAMTT183 & $29-52$ / 25-52 & 2 & 1.01 \\
\hline Height at & 5 & $<0.001$ & 124 & BM315 & $116-134 / 116-136$ & 3 & 1.10 \\
\hline \multirow[t]{2}{*}{ Sacrum } & 6 & 0.24 & 54 & BM1329 & $43-63 / 36-75$ & 3 & 0.64 \\
\hline & 13 & 0.40 & 74 & ABS10 & $62-96 / 22-108$ & 2 & 1.29 \\
\hline \multirow[t]{2}{*}{ Rump length } & 5 & 0.27 & 124 & BM315 & $114-128 / 54-128$ & 2 & 1.01 \\
\hline & 20 & 0.30 & 34 & TGLA126 & $22-48 / 17-48$ & 2 & 0.65 \\
\hline \multirow[t]{4}{*}{ Rump width } & 5 & 0.03 & 124 & BM315 & $110-124 / 67-124$ & 3 & 0.94 \\
\hline & 6 & 0.32 & 62 & DIK82 & $37-85$ / 30-123 & 3 & 0.74 \\
\hline & 8 & 0.07 & 140 & $B M S 2847$ & $124-140 / 46-144$ & 4 & 0.87 \\
\hline & 20 & 0.31 & 24 & TGLA126 & $15-38 / 12-40$ & 2 & 0.68 \\
\hline \multirow[t]{3}{*}{ Rump angle } & 1 & 0.15 & 40 & BM4307 & $23-58 / 26-103$ & 4 & 0.60 \\
\hline & 13 & 0.06 & 54 & HUJ616 & $42-66$ / 39-66 & 3 & 0.82 \\
\hline & 19 & 0.23 & 118 & ETH3 & $100-135 / 29-135$ & 4 & 0.99 \\
\hline Heel depth & 15 & 0.31 & 30 & $B M S 2684$ & $22-35 / 18-38$ & 3 & 1.09 \\
\hline
\end{tabular}

(1) Location in cM Haldane (see Tab. I).

(2) $[95 \%$ Lod Drop-off confidence interval] / [90\% Bootstrap confidence interval]. 
Table V. QTL with a chromosomewise significance level $(P)$ ranging from 0.34 to $1 \%$.

\begin{tabular}{|c|c|c|c|c|c|c|c|}
\hline Trait & $\begin{array}{l}\text { Chromo- } \\
\text { some }\end{array}$ & $\begin{array}{c}\text { Location } \\
\text { of } \\
\text { maximum }^{(1)}\end{array}$ & $P(\%)$ & Closest marker & $\begin{array}{l}\text { Location confidence } \\
\text { interval }(\mathrm{cM})^{(2)}\end{array}$ & $\begin{array}{c}\text { Number of } \\
\text { hetero- } \\
\text { zygous } \\
\text { sires }\end{array}$ & $\begin{array}{c}\text { Average } \\
\text { substitu- } \\
\text { tion effect } \\
\quad\left(\sigma_{g}\right)\end{array}$ \\
\hline Milk & 7 & 84 & 0.9 & INRABERI92 & $71-92 / 10-120$ & 3 & 0.67 \\
\hline Fat & 7 & 84 & 0.6 & $R M 6$ & $60-92 / 5-120$ & 2 & 0.72 \\
\hline Protein & 19 & 138 & 0.8 & ETH3 & $120-147 / 50-145$ & 3 & 1.00 \\
\hline Fat percent & 7 & 76 & 0.4 & INRABERI92 & 52-99 / 11-135 & 1 & 0.79 \\
\hline \multirow[t]{2}{*}{ Protein percent } & 3 & 24 & 1.0 & ILSTSO96 & $6-32 / 13-123$ & 4 & 0.63 \\
\hline & 18 & 10 & 0.8 & $A B S 13$ & $0-27 / 0-118$ & 2 & 0.84 \\
\hline SCS & 10 & 86 & 0.9 & $D I K 20$ & $66-90 / 6-92$ & 3 & 0.62 \\
\hline \multirow[t]{3}{*}{ Milking speed } & 6 & 160 & 0.8 & BM2320 & $132-160 / 72-160$ & 1 & 0.40 \\
\hline & 8 & 50 & 0.8 & BMS678 & $28-58 / 12-60$ & 3 & 0.37 \\
\hline & 13 & 94 & 0.8 & ABS10 & $85-105 / 72-103$ & 3 & 0.54 \\
\hline \multirow[t]{2}{*}{ Fertility } & 1 & 62 & 0.5 & INRA073 & $49-100 / 50-133$ & 3 & 1.12 \\
\hline & 7 & 120 & 0.37 & INRA053 & $116-122 / 91-125$ & 2 & 1.16 \\
\hline \multirow[t]{2}{*}{ Udder balance } & 9 & 48 & 0.6 & UWCA9 & $40-56$ / 37-90 & 3 & 0.53 \\
\hline & 20 & 30 & 0.6 & TGLA126 & $8-32 / 6-58$ & 2 & 0.75 \\
\hline $\begin{array}{l}\text { Teat distance } \\
\text { side view }\end{array}$ & 2 & 38 & 0.39 & CSSM042 & $22-53 / 19-61$ & 2 & 0.65 \\
\hline $\begin{array}{l}\text { Teat placement } \\
\text { front }\end{array}$ & 28 & 4 & 0.6 & $I D V G A 8$ & $0-60 / 0-64$ & 2 & 0.91 \\
\hline \multirow[t]{3}{*}{ Chest depth } & 2 & 40 & 0.6 & CSSM042 & $33-50 / 32-135$ & 1 & 1.08 \\
\hline & 5 & 124 & 1.0 & BM315 & $104-129 / 10-135$ & 3 & 0.85 \\
\hline & 9 & 127 & 0.7 & BMS1967 & $114-127 / 14-127$ & 4 & 0.89 \\
\hline \multirow[t]{2}{*}{ Rump angle } & 11 & 146 & 0.7 & $B M S 2208$ & $132-184 / 30-178$ & 3 & 0.89 \\
\hline & 17 & 8 & 0.5 & BMS499 & $0-30 / 2-88$ & 2 & 1.22 \\
\hline Heel depth & 7 & 32 & 0.8 & BM741 & $20-40 / 14-120$ & 1 & 3.80 \\
\hline
\end{tabular}

and, on the other hand, by the size of the overall design and of each individual family. Only large families were selected to guarantee the highest detection power. According to [32], such a design should provide a detection power greater than $90 \%$ for biallelic QTL with balanced frequencies and substitution effects greater than 0.5 genetic standard deviation. The actual detection power is likely to be lower because QTL allele frequencies are not balanced. This was clearly shown by the small number (1-5 out of 14) of heterozygous sires for each detected QTL. This likely reflects the small number of alleles with 
Table VI. QTL detected with a chromosomewise significance level $(P)$ ranging from 1 to $3 \%$. (continued on the next page)

\begin{tabular}{|c|c|c|c|c|c|}
\hline Trait & $\begin{array}{l}\text { Chromo- } \\
\text { some }\end{array}$ & $\begin{array}{c}\text { Location } \\
\text { of } \\
\text { maximum }^{(1)}\end{array}$ & Closest marker & $P(\%)$ & $\begin{array}{l}\text { Number of } \\
\text { heterozygous } \\
\text { sires }\end{array}$ \\
\hline \multirow[t]{3}{*}{ Milk } & 11 & 128 & INRABERN162 & 1.8 & 2 \\
\hline & 19 & 129 & BMC1113 & 3.0 & 1 \\
\hline & 26 & 56 & IDVGA56 & 2.1 & 2 \\
\hline \multirow[t]{2}{*}{ Protein } & 17 & 87 & BM1862 & 2.3 & 1 \\
\hline & 22 & 16 & CSSM026 & 2.7 & 1 \\
\hline \multirow[t]{3}{*}{ Fat percent } & 15 & 84 & IOBT395 & 1.8 & 1 \\
\hline & 19 & 93 & BMS1069 & 1.6 & 3 \\
\hline & 22 & 106 & UWCA49 & 2.3 & 2 \\
\hline Protein percent & 15 & 84 & $B M S 2684$ & 2.2 & 1 \\
\hline Persistency & 17 & 70 & CSSM033 & 1.4 & 3 \\
\hline \multirow[t]{3}{*}{ SCS } & 9 & 125 & BMS1967 & 1.3 & 2 \\
\hline & 21 & 90 & TGLA122 & 1.5 & 1 \\
\hline & 23 & 19 & RM33 & 1.7 & 2 \\
\hline \multirow[t]{3}{*}{ Milking speed } & 5 & 97 & CSSM022 & 1.3 & 2 \\
\hline & 19 & 94 & BMS1069 & 1.7 & 3 \\
\hline & 22 & 38 & CSSM006 & 1.4 & 2 \\
\hline \multirow[t]{3}{*}{ Fertility } & 10 & 95 & CSSM039 & 2.4 & 3 \\
\hline & 20 & 75 & $U W C A 26$ & 1.5 & 3 \\
\hline & 21 & 56 & ILSTS103 & 1.4 & 3 \\
\hline \multirow[t]{3}{*}{ Udder cleft } & 10 & 55 & INRA071 & 1.8 & 3 \\
\hline & 20 & 9 & BM1225 & 1.2 & 2 \\
\hline & 25 & 78 & INRA222 & 1.6 & 2 \\
\hline \multirow[t]{7}{*}{ Udder depth } & 4 & 44 & $R M 188$ & 2.6 & 2 \\
\hline & 6 & 147 & BM2320 & 2.6 & 3 \\
\hline & 9 & 100 & INRAI44 & 1.1 & 3 \\
\hline & 10 & 49 & INRA071 & 2.5 & 1 \\
\hline & 13 & 96 & $A B S 10$ & 2.3 & 3 \\
\hline & 20 & 14 & $B M 1225$ & 1.0 & 3 \\
\hline & 21 & 10 & BM8115 & 1.2 & 2 \\
\hline \multirow[t]{3}{*}{ Udder balance } & 1 & 49 & BM4307 & 1.9 & 2 \\
\hline & 14 & 0 & CSSM066 & 3.0 & 2 \\
\hline & 21 & 24 & BP33 & 1.6 & 1 \\
\hline
\end{tabular}


Table VI. Continued.

\begin{tabular}{|c|c|c|c|c|c|}
\hline Trait & $\begin{array}{l}\text { Chromo- } \\
\text { some }\end{array}$ & $\begin{array}{c}\text { Location } \\
\text { of } \\
\text { maximum }^{(1)}\end{array}$ & Closest marker & $P(\%)$ & $\begin{array}{l}\text { Number of } \\
\text { heterozygous } \\
\text { sires }\end{array}$ \\
\hline Teat distance & 4 & 35 & RM188 & 1.4 & 1 \\
\hline \multirow[t]{3}{*}{ side view } & 10 & 42 & INRA071 & 2.2 & 2 \\
\hline & 11 & 100 & INRA177 & 2.4 & 1 \\
\hline & 18 & 115 & TGLA227 & 2.3 & 2 \\
\hline \multirow{3}{*}{$\begin{array}{l}\text { Teat placement } \\
\text { front }\end{array}$} & 6 & 87 & $I N R A K$ & 2.4 & 3 \\
\hline & 9 & 56 & UWCA9 & 2.4 & 2 \\
\hline & 17 & 87 & BM1862 & 2.0 & 2 \\
\hline \multirow[t]{4}{*}{ Implantation } & 2 & 34 & TGLA377 & 2.9 & 3 \\
\hline & 8 & 88 & HEL9 & 1.6 & 4 \\
\hline & 9 & 99 & INRA144 & 2.3 & 2 \\
\hline & 15 & 26 & INRA224 & 1.3 & 2 \\
\hline \multirow{3}{*}{$\begin{array}{l}\text { Rear udder } \\
\text { attachment }\end{array}$} & 5 & 45 & RM500 & 1.7 & 3 \\
\hline & 6 & 162 & BM2320 & 1.4 & 1 \\
\hline & 9 & 42 & UWCA9 & 1.4 & 2 \\
\hline \multirow[t]{6}{*}{ Teat length } & 2 & 58 & CSSM042 & 2.7 & 2 \\
\hline & 6 & 65 & DIK82 & 2.8 & 1 \\
\hline & 8 & 135 & $B M S 2847$ & 1.5 & 1 \\
\hline & 13 & 0 & $T G L A 23$ & 1.8 & 2 \\
\hline & 21 & 12 & BP33 & 1.6 & 2 \\
\hline & 28 & 40 & $I D V G A 43$ & 1.8 & 3 \\
\hline \multirow[t]{2}{*}{ Height at sacrum } & 2 & 36 & TGLA377 & 1.0 & 2 \\
\hline & 11 & 82 & BMS1822 & 1.4 & 2 \\
\hline \multirow[t]{4}{*}{ Chest depth } & 1 & 83 & INRA073 & 2.6 & 2 \\
\hline & 11 & 86 & INRA177 & 2.7 & 1 \\
\hline & 20 & 14 & $B M 1225$ & 2.1 & 3 \\
\hline & 24 & 56 & ILSTS031 & 1.0 & 1 \\
\hline \multirow[t]{3}{*}{ Rump length } & 1 & 93 & INRA073 & 3.0 & 2 \\
\hline & 11 & 36 & INRA177 & 1.3 & 2 \\
\hline & 28 & 37 & $I D V G A 43$ & 1.8 & 3 \\
\hline Rump width & 11 & 82 & BMS1822 & 2.3 & 4 \\
\hline \multirow[t]{2}{*}{ Rump angle } & 8 & 48 & BMS678 & 1.1 & 2 \\
\hline & 28 & 56 & IDVGA 8 & 1.3 & 1 \\
\hline \multirow[t]{2}{*}{ Heel depth } & 9 & 32 & BM2504 & 1.7 & 2 \\
\hline & 18 & 74 & ILSTSOO2 & 2.3 & 2 \\
\hline
\end{tabular}

(1) Location in cM Haldane (see Tab. I). 

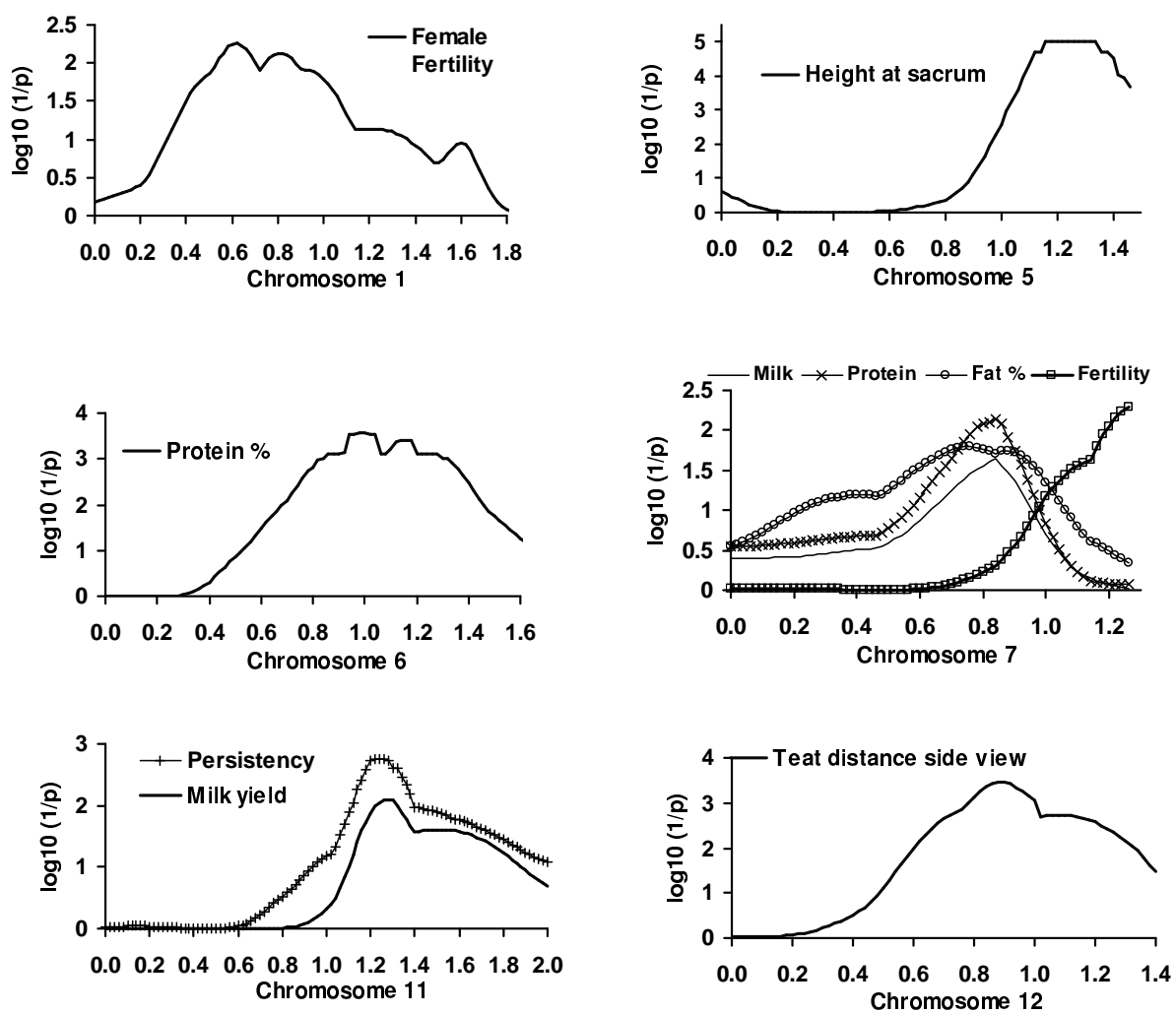

Figure 3. Location score profiles, expressed as $\log _{10}(1 / P)$, for 12 chromosomes. The critical probability $P$ at each location is obtained by the comparison of the observed likelihood ratio test at this location with the distribution under H0 (obtained by permutation) of the maximum LRT over the chromosome. As 100000 permutations were performed, $\log _{10}(1 / P)$ is bounded to 5 .

very different effects and/or the rather low frequency of the QTL alleles with an extreme effect. Consequently, only a small part of the design contributes to the detection of a given QTL and a typical design with 10-20 families could miss a QTL when no family is informative. Assuming a biallelic QTL with unbalanced frequencies 0.1 and 0.9 (compatible with $20 \%$ heterozygous sires) and a substitution effect of $0.7 \sigma_{g}$, the actual detection power of our design is around $70 \%$ and is still quite high.

One hundred and twenty QTL results were tabulated. Of course, 15 to 20 were probably false positives, and were most likely those with $P$-values between 1 and 3\%. But conversely, this experiment showed that the number of true QTL is likely to be higher. Indeed, the number of H1 hypotheses could be roughly estimated from the observed distribution of the tests. Assuming a uniform distribution of the $P$-values when $\mathrm{H} 0$ is true and also assuming that all 

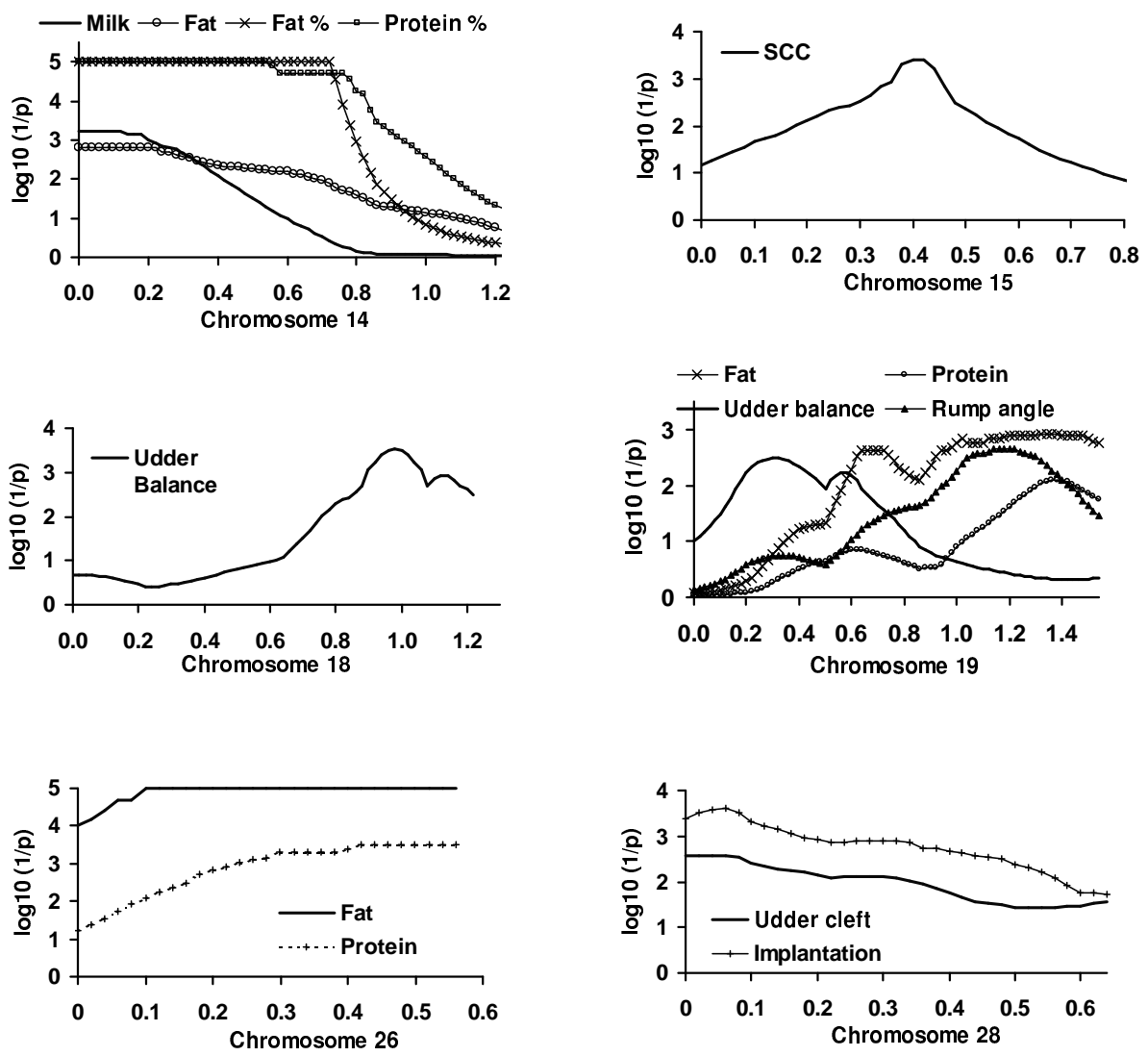

Figure 3. Continued. Location score profiles, expressed as $\log _{10}(1 / P)$, for 12 chromosomes. The critical probability $P$ at each location is obtained by the comparison of the observed likelihood ratio test at this location with the distribution under $\mathrm{H} 0$ (obtained by permutation) of the maximum LRT over the chromosome. As 100000 permutations were performed, $\log _{10}(1 / P)$ is bounded to 5 .

$P$-values greater than $50 \%$ corresponded to true $\mathrm{H} 0$ situations, the number of true $\mathrm{H} 0$ situations could be estimated by twice the number of results in the [50, 100] $P$-value interval. This method led to $364 \mathrm{H} 0$ situations only, and therefore to $696-364=332 \mathrm{H} 1$ situations. This value is much larger than the number of results tabulated.

QTL were detected for all traits, even those with a very low heritability like fertility, although the reliability of the bull evaluations was below 0.50 for this trait. This was predicted by the theory. As pointed out by [32], the residual variance in a granddaughter design is equal to $3 / 16 h^{2} \sigma_{p}^{2}+\left(1-h^{2} / 4\right) \sigma_{p}^{2} / \mathrm{nd}$ (where $\sigma_{p}^{2}$ is the phenotypic variance), and decreases with the heritability when the number of granddaughters per son (nd) is large enough. Consequently, 
Table VII. Estimates of the proportion of variance due to some QTL in the total genetic variance.

\begin{tabular}{clr}
\hline Chromosome & \multicolumn{1}{c}{ Trait } & Proportion (\%) \\
\hline 1 & Fertility & 15 \\
3 & Protein content & 7 \\
6 & Protein content & 18 \\
6 & Milking speed & 13 \\
7 & Protein & 8 \\
7 & Fertility & 16 \\
8 & Milking speed & 8 \\
9 & Cell counts & 7 \\
11 & Persistency & 8 \\
13 & Milking speed & 9 \\
14 & Milk yield & 13 \\
14 & Fat & 9 \\
14 & Fat content & 40 \\
14 & Protein content & 30 \\
15 & Cell counts & 9 \\
18 & Protein content & 9 \\
19 & Fat & 9 \\
19 & Protein & 17 \\
20 & Protein content & 7 \\
26 & Fat & 16 \\
26 & Protein & 10 \\
\hline
\end{tabular}

Table VIII. Results of the 2-QTL analysis.

\begin{tabular}{clccc}
\hline Chromosome & \multicolumn{1}{c}{ Trait } & Locations $^{(1)}$ & $\begin{array}{c}\text { P(2 QTL } v s . \\
\text { QTL1), } \%\end{array}$ & $\begin{array}{c}\text { P(2 QTL vs. } \\
\text { QTL2), \% }\end{array}$ \\
\hline 1 & Fertility & 85,163 & 5.0 & 3.2 \\
5 & Rump width & 75,124 & 1.6 & 5.0 \\
18 & Protein yield & 58,70 & 3.0 & 2.0 \\
19 & Fat yield & 67,155 & 3.8 & 4.0 \\
24 & Heel depth & 17,45 & 2.2 & 4.8 \\
\hline
\end{tabular}

(1) Location in cM Haldane (see Tab. I).

the detection power increases when the heritability decreases, if the number of granddaughters per son is high.

The estimates of the QTL effects were rather homogeneous and most substitution effects in the informative families ranged from 0.6 to 1 genetic standard 


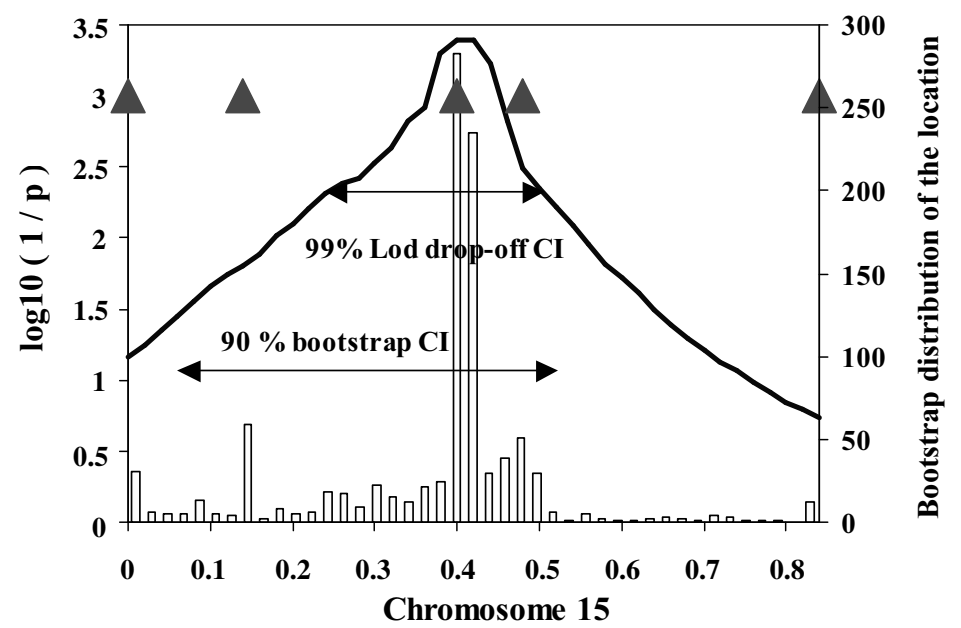

Figure 4. Location score profile, expressed as $\log _{10}(1 / P)$, for somatic cell score on chromosome 15 and bootstrap distribution of the estimated locations. Triangles show the location of the markers.

deviation. Note that this mode of expression is preferable in a granddaughter design, because the variability of twice the DYD tends to the genetic variance when the number of granddaughters is large. This relative homogeneity in the estimates could be explained as follows. On the one hand, smaller effects are difficult to detect and would require many informative families. On the other hand, larger true effects are likely to be rare, and because this design included large families, the effects were probably not strongly overestimated. Some effect estimates, as for heel depth on chromosome 7 (3.8 genetic standard deviations), were much larger and were likely overestimated.

The most significant QTL is located close to the centromer of chromosome 14 and it affects the production traits and particularly fat content. Its effect also exceeds the usual range and reached 1.25 genetic standard deviations. In fact, this QTL, already found in different studies, could be considered as a major gene. It probably has two alleles only, with a strong substitution effect and it explains $40 \%$ of the genetic variability in this design and around $50 \%$ in the Holstein breed. Before its detection with genetic markers, its existence was already postulated [5] to explain a clear deviation to the polygenic model in this breed, the large increase in fat content heritability and changes in genetic correlations between fat content and other production traits. This QTL has recently been characterised [14]. It corresponds to a mutation of the DGAT1 gene which encodes an enzyme involved in the fatty acid synthesis.

Except for chromosome 14 on fat (and protein) content, the part of genetic variance explained by each QTL was rather low and ranged from 6 to $18 \%$. 
These values are quite limited. For a given trait, several QTL were necessary to explain a substantial part of the genetic variability and, in most situations, the major part of the genetic variability remained unexplained.

The literature is rather abundant for production and milk composition but more rare for functional traits. For production and milk composition, many results often reported in the literature were confirmed, particularly on chromosomes 3, 6, 7, 14, 20, and 26 [1,2,8,12, 15,22,23, 25,26,30,34]. Other QTL on chromosomes 1,17 and 23 reported by several authors were less clear in the present study ( $P=3.9 \%$ and $2.3 \%$ for chromosome 1 and 17, respectively) or not detected (chromosome 23). A clear QTL affecting production was also detected on chromosome 19 and was in agreement with [21] although it was not confirmed by any large scale study. Several new QTL were found, on chromosome 11 for persistency, and on chromosome 18 for contents. Finally, the number of QTL found for milk and protein yields was rather limited, whereas the number of QTL affecting fat yield, fat or protein contents was greater. The low number of QTL found for milk yield (and protein yield, which is highly correlated) could be explained by the intense selection over time, whereas milk composition was less selected. But the situation of fat yield, with several strong QTL, is more surprising.

When a chromosomal region was found to affect several traits, the estimated effects were in agreement with the genetic correlations. However, in many situations, fat and protein contents were not affected by the same QTL, showing that fat and protein could be disentangled. Similarly, several QTL were found to affect contents, whereas milk yield, although negatively correlated to the contents, was not affected. Again, the QTL on chromosome 14 was an exception. Although milk and fat yields were positively correlated, QTL effects on these two traits were in the opposite directions, illustrating the dramatic effect of this QTL on fat content.

Four QTL were found for somatic cell counts, on chromosome 9, 10, 15, and 21. The latter result was already reported by [15] and the others were original. None of these QTL co-segregated with QTL for udder type or milking speed, suggesting that their mechanism is not related to the udder shape or teat elasticity. In contrast with [24], no effect was found on chromosome 23, although this chromosome carries the major histocompatibility complex (Bola) known to be deeply involved in the infection resistance mechanism. Similarly, the QTL on chromosome 26 detected by [34] was not confirmed.

Three QTL were also found for fertility on chromosome 1, 7, and 21, and this is the first time that significant QTL are reported for this trait. Only one QTL, on chromosome 7, could be linked to production, and may reflect the antagonistic genetic correlation between fertility and production, although the QTL of fertility seems to be more telomeric. On chromosome 1, the confidence interval of the location was particularly large and the peak of 
individual families suggested the presence of several linked QTL. The 2-QTL analysis also suggested the presence of two linked QTL.

Several QTL were found to affect the stature on chromosomes 2, 5, 6, and 13. On the telomeric part of chromosome 5, the likelihood ratio test for the height at the sacrum by far exceeded the highest individual value obtained under $\mathrm{H} 0$ in the 100000 permutations. The estimated effect reached 1.1 genetic standard deviations in two families and could be considered as a major gene. This QTL was already reported by [27].

Udder depth is the most interesting udder trait for selection purposes, because it is the best morphological predictor of mastitis resistance and longevity. It was characterised by many (9) putative QTL with a chromosome-wise significance level ranging from 1 to $4 \%$, but no highly significant QTL was found. This disappointing result could likely be attributed to the composite definition of this trait and, therefore, its determinism more complex than for more analytical traits.

Three different breeds were used and it would be interesting to determine whether some QTL are breed-specific. In fact, it remains difficult to answer this question because the number of Montbéliarde or Normande families was limited ( 2 and 3, respectively) and because the number of informative families was also very small ( 1 to 5 , and 3 on average). The analysis of additional families is needed to address this point. Nevertheless, much less QTL were found in the Normande breed than in the two other breeds but this may be at least partly explained by the smaller size of the three Normande families. We also believe that the genetic determinism of fat content is very specific in the Holstein breed and this is likely due to the QTL carried by chromosome 14 . Although this gene is not specific to the Holstein, it is responsible for a much larger part of the genetic variance in this breed than in the others, probably because of very different allelic frequencies.

In all cases, the location confidence intervals were extremely large. This disappointing result was expected. With only a few informative families, QTL locations were estimated with 150-300 informative meioses. This clearly shows that this design should be expanded in terms of the number of markers but also in terms of the number of informative families in order to obtain more reasonable confidence intervals compatible with marker-assisted selection and fine mapping techniques.

As expected, the 2-QTL analysis provided very limited results. Two linked QTL can be distinguished in the same families only when they are separated by two informative markers, a rather rare situation in this design. Linked QTL for milk composition on chromosomes 3,6 , or 20 , suggested by different studies were not found here. Nevertheless, two linked QTL were suggested for protein yield on chromosome 18, fat yield on chromosome 19, fertility on chromosome 1 , rump width on chromosome 5 , and heel depth on chromosome 24 . On 
chromosome 15, the strong QTL effect detected for the somatic cell score could result from two rather close QTL $(20 \mathrm{cM})$ segregating in different families. In practice, little results were expected from this two-QTL analysis because of the limited density of the marker map.

To confirm QTL, Coppieters et al. [9] proposed to analyse the maternal information. In a granddaughter design, the number of sons per dam is too small to analyse within-dam segregations. But when the dams originate from a limited number of maternal grandsires, QTL detection can be carried out within maternal grandsires. Bolard and Boichard [6] extended their approach in the case where dams and maternal grand sires are not genotyped. Applied to this design, this method confirmed many QTL described in the present study.

In most situations, the confidence interval of the location was very large and it was impossible to test for two linked QTL, emphasizing the need for a denser marker map and for even larger families. The QTL effects, however, are quite large and very attractive for MAS. A strong limitation is the small number of heterozygous sires and the unknown status of the homozygous ones. Therefore, this project is continued into three different directions by adding new families in the analysis, by working on the fine mapping and the characterisation of some QTL, and by using some of these results in marker-assisted selection.

\section{ACKNOWLEDGEMENTS}

This program was supported by the French AI industry (UNCEIA), and by a grant of the Groupe d'étude et de recherche sur les génomes (GREG). D. Boichard is grateful to the "Mathématiques and marqueurs moléculaires" (MMM) Inra group for continuous discussions and for the joint development of the QTL analysis software. V. Ducrocq and H. Larroque are gratefully acknowledged for providing the type evaluations.

\section{REFERENCES}

[1] Arranz J.J., Coppieters W., Berzi P., Cambisano N., Grisart B., Karim L., Marcq F., Moreau L., Nezer C., Riquet J., Simon P., Vanmanshoven P., Wagenaar D., Georges M., A QTL affecting milk yield and composition maps to bovine chromosome 20: a confirmation, Anim Genet. 29 (1998) 107-115.

[2] Ashwell M.S., Van Tassell C.P., Sonstegard T.S., A genome scan to identify quantitative trait loci affecting economically important traits in a US Holstein population, J. Dairy Sci. 84 (2001) 2535-2542.

[3] Barendse W., Vaiman D., Kemp S.J., Sugimoto Y., et al., A medium-density genetic linkage map of the bovine genome, Mamm. Genome 8 (1997) 21-28.

[4] Bennewitz J., Reinsch N., Kalm E., Proposals for improved bootstrap confidence intervals in QTL. Proc 51st Ann. Meet. Eur. Assoc. Anim. Prod., The Hague, The Netherlands (2000). Paper G1.9. 
[5] Boichard D., Elsen J.M., Le Roy P., Bonaïti B., Segregation analysis of fat content data in Holstein $\times$ European Friesian crossbred cattle. 4th World Cong. Genet. Appl. Livest. Prod., Edinburgh, Scotland. 14, 4th WCGALP Congress office, 1990, University of Edinburgh, Scotland, pp. 167-170.

[6] Bolard M., Boichard D., Use of maternal information for QTL detection in a (grand)daughter design, Genet. Sel. Evol. 34 (2002) 335-352.

[7] Churchill G.A., Doerge R.W., Empirical threshold values for quantitative trait mapping, Genetics. 138 (1994) 963-971.

[8] Coppieters W., Riquet J., Arranz J.J., Berzi P., Cambisano N., Grisart B., Karim L., Marcq F., Moreau L., Nezer C., Riquet J., Simon P., Vanmanshoven P., Wagenaar D., Georges M., A QTL with major effect on milk yield and composition maps to bovine chromosome 14, Mamm. Genome 9 (1998) 540-544.

[9] Coppieters W., Kvasz A., Arranz J.J., Grisard B., Farnir F., Riquet J., Georges M., The great-grand-daughter design: a simple strategy to increase the power of a grand-daughter design for QTL mapping, Genet. Res. Camb. 74 (1999) 189-199.

[10] Elsen J.M., Mangin B., Goffinet B., Boichard D., Le Roy P., Alternative models for QTL detection in livestock. I. General information, Genet. Sel. Evol. 31 (1999) 213-224.

[11] Geldermann H., Investigations on inheritance of quantitative characters in animals by gene markers, Theor. Appl. Genet. 46 (1975) 319-330.

[12] Georges M., Nielsen D., Makinnon M., Mishra A., Okimoto R., Pasquino A.T., Sargeant L.S., Sorensen A., Steele M.R., Zhao X., Womack J.E., Hoeschele I., Mapping quantitative trait loci controlling milk production in dairy cattle by exploiting progeny testing, Genetics 139 (1995) 907-920.

[13] Goffinet B., Boichard D., Le Roy P., Elsen J.M., Mangin B., Alternative models for QTL detection in livestock. III. Heteroskedastic model and models corresponding to several distributions of the QTL effect, Genet. Sel. Evol. 31 (1999) 341-350.

[14] Grisard B., Coppieters W., Farnir F., Karim L., Ford C., Berzi P., Cambisano N., Mni M., Reid S., Simon P., Spelman R., Georges M., Snell R., Positional candidate cloning of a QTL in dairy cattle: identification of a missense mutation in the bovine DGAT1 gene with a major effect on milk yield and composition, Genome Res. 12 (2001) 222-231.

[15] Heyen D.W., Weller J.I., Ron M., Gand M., Feldmesser E., Da Y., Wiggans G.R., VanRaden P.M., Lewin H.A., A genome scan for quantitative trait loci influencing milk production and health traits in dairy cattle, Physiol. Genomics 1 (1999) 165-175.

[16] Iannucelli E., Woloszin N., Arhainx J., Gellin J., Milan D., Gemma: a database to manage and automate microsatellite genotyping, 25th Congr. Int. Soc. Anim. Genet., 21-25 July 1996, Tours, France, Anim. Genet. 27 (1996) Suppl 2, 55.

[17] Interbull, Sire evaluation procedures for non dairy production traits practised in various countries, Interbull. Bull. 13, 1996, Upssala, Sweden.

[18] Interbull, National genetic evaluation programmes for dairy production traits practised in Interbull member countries, Interbull. Bull. 24, 2000, Upssala, Sweden. 
[19] Kappes S.M., Keele J.W., Stone R.T., McGraw R.A., Sonstegard T.S., Smith T.P., Lopez-Corrales N.L., Beattie C.W., A second-generation linkage map of the bovine genome, Genome Res. 7 (1997) 235-249.

[20] Knott S.A., Elsen J.M., Haley C.S., Methods for multiple marker mapping of quantitative trait loci in half-sib populations, Theor. Appl. Genet. 93 (1996) 71-80.

[21] Lagziel A., Lipkin E., Ezra E., Soller M., Weller J.I., An MspI polymorphism at the bovine growth hormone $(\mathrm{gGH})$ gene is linked to a locus affecting milk protein percentage, Anim. Genet. 30 (1999) 296-299.

[22] Mosig M.O., Lipkin E., Khutoreskaya G., Tchourzyna E., Soller M., Friedmann A., A whole genome scan for quantitative trait loci affecting milk protein percentage in Israeli-Holstein cattle, by means of selective milk DNA pooling in a daughter design, using an adjusted false discovery rate criterion, Genetics 157 (2001) 1683-1698.

[23] Plante Y., Gibson J.P., Nadesalingam J., Mehrabani-Yeganeh H., Lefebvre S., Vandervoort G., Jansen G.B., Detection of quantitative trait loci affecting milk production traits on 10 chromosomes in Holstein cattle, J. Dairy Sci. 84 (2001) 1516-1524.

[24] Reinsch N., Xu N., Thomsen H., Looft C., Kalm E., Grupe S., Kuhn C., Schwerin M., Leyhe B., Hienleder S., Erhard G., Medjugorac I., Russ I., Forster M., Brenig B., Reents R., Averdunk G., First results on somatic cell counts loci form the ADR bovine mapping project. Proc. 6th World Cong. Genet. Appl. Livest. Prod., 26, 6th WCGALP Congress office, 1998, University of New England, Armidale, Australia, pp. 426-428.

[25] Ron M., Heyen D.W., Weller J.I., Band M., Feldmesser E., Pasternak H., Da Y., Wiggans G.R., VanRaden P.M., Ezra E., Lewin H.A., Detection and analysis of a locus affecting milk concentration in a US and Israeli dairy cattle population. Proc. 6th World Congr. Genet. Appl. Livest. Prod., 26, 6th WCGALP Congress office, 1998, University of New England, Armidale, Australia, pp. 422-425.

[26] Spelman R., Coppieters W., Karim L., van Arendonk J.A.M., Bovenhuis H., Quantitative trait locus analysis for five milk production traits on chromosome six in the Dutch Holstein Friesian population, Genetics 144 (1996) 1799-1808.

[27] Schrooten C., Bovenhuis H., Coppieters W., van Arendonk J.A.M., Whole genome scan to detect quantitative trait loci for conformation and functional traits in dairy cattle, J. Dairy Sci. 83 (2000) 795-806.

[28] Thomsen H., Reinsch N., Xu N., Looft C., Grupe S., Kuhn C., Brockmann G.A., Schwerin M., Leyhe-Horn B., Hiendleder S., Erhardt G., Medjugorac I., Russ I., Förster M., Brenig B., Reinhardt F., Reents R., Blümel J., Averdunk G., Kalm E., Polygenic inheritance of the bovine blood group systems F, J, R, and Z, determined by loci on different chromosomes. 50th Ann. Meet. Eur. Assoc. Anim. Prod., Zurich, Swizerland, 22-26/08/1999. Paper G4.10.

[29] VanRaden P.M., Wiggans G.R., Derivation, calculation, and use of national animal model information, J. Dairy Sci. 76 (1991) 2737-2746.

[30] Vilkki H.J., de Konning D.J., Elo K., Velmala R., Maki-Tanila A., Multiple marker mapping of quantitative trait loci of Finnish dairy cattle by regression, J. Dairy Sci. 80 (1997) 198-204. 
[31] Visscher P.M., Thompson R., Haley C.S., Confidence intervals in QTL mapping by bootstraping, Genetics 143 (1996) 1013-1020.

[32] Weller J.I., Kashi Y., Soller M., Power of daughter and granddaughter designs for determining linkage between marker loci and quantitative trait loci in dairy cattle, J. Dairy Sci. 73 (1990) 2525-2537.

[33] Weller J.I., Song J.Z., Heyen D.W., Lewin H.A., Ron M., A new approach to the problem of multiple comparisons in the genetic dissection of complex traits, Genetics 150 (1998) 1699-1706.

[34] Zhang Q., Boichard D., Hoeschele I., Ernst C., Eggen A., Murkve B., PfisterGenskow M., Witte L.A., Grignola F.E., Uimari P., Thaller G., Bishop M.D., Mapping quantitative trait loci for milk production and health of dairy cattle in a large outbred pedigree, Genetics 149 (1998) 1959-1973.

To access this journal online: www.edpsciences.org 